\title{
Ketahanan Masyarakat terhadap Ancaman Krisis Energi Listrik di Kabupaten Lampung Selatan, Provinsi Lampung
}

\author{
Helmia Adita Fitra ${ }^{1}$ \\ Program Studi Perencanaan Wilayah dan Kota \\ Institut Teknologi Sumatera, Lampung Selatan, Indonesia
}

\author{
Asirin \\ Program Studi Perencanaan Wilayah dan Kota \\ Institut Teknologi Sumatera, Lampung Selatan, Indonesia
}

Artikel Masuk : 1 Februari 2018

Artikel Diterima : 23 Februari 2018

Tersedia Online : 29 April 2018

\begin{abstract}
Abstrak: Provinsi Lampung menghadapi permasalahan krisis energi. Akibat defisit daya listrik yang mencapai 200 Megawatt (MW), pemadaman aliran listrik di beberapa wilayah Provinsi Lampung terus terjadi. Sebagai salah satu kecamatan yang ada di Kabupaten Lampung Selatan, Kecamatan Jati Agung berlokasi dekat dengan Kota Bandar Lampung. Di Kecamatan Jati Agung terdapat akses pintu masuk dan keluar jalan bebas hambatan (tol) TransSumatera. Selain itu terdapat pusat aktivitas pendidikan baru, Institut Teknologi Sumatera (ITERA), dan aktivitas pemerintahan baru yaitu Kota Baru. Sebagai daerah yang berpotensi cepat tumbuh, Kecamatan Jati Agung memerlukan strategi ketahanan masyarakat yang dapat menjawab ancaman krisis energi yang terjadi. Penelitian ini bertujuan untuk memetakan dimensi ketahanan masyarakat terhadap ancaman krisis energi listrik di Kecamatan Jati Agung, Lampung Selatan berdasarkan persepsi masyarakat dalam hal ini rumah tangga di wilayah studi. Studi ini diharapkan menghasilkan kajian mengenai bagaimana ketahanan pada masing-masing dimensi terhadap pemadaman listrik di wilayah studi. Dimensi ketahanan masyarakat dikategorikan menjadi empat yaitu 1) Kesehatan dan Kesejahteraan, 2) Ekonomi dan Sosial, 3) Lingkungan dan Infrastruktur, dan 4) Kepemimpinan dan Strategi. Penelitian ini menggunakan analisis deskriptif statistik yang menjelaskan hasil penilaian ketahanan masyarakat dengan menggunakan skala Likert pada masing-masing faktor penggerak dimensi. Hasil temuan penelitian ini menunjukkan bahwa dari keempat dimensi, dimensi Kepemimpinan dan Strategi merupakan dimensi yang paling "tidak berketahanan" terhadap ancaman krisis energi listrik.
\end{abstract}

Kata kunci: energi listrik, ketahanan masyarakat, krisis energi, Lampung, skala Likert

Abstract: Lampung Province is facing energy crisis problems. Due to the deficit of electricity supplies which is up to 200 Megawatt (MW), power shutdowns have emerged in many areas of Lampung Province. As one of the districts in South Lampung Regency, Jati Agung is

\footnotetext{
${ }^{1}$ Korespondensi Penulis: Program Studi Perencanaan Wilayah dan Kota, Institut Teknologi Sumatera, Lampung Selat an, Indonesia Email: helmia@pwk.itera.ac.id
} 


\section{Ketahanan Masyarakat terhadap Ancaman Krisis Energi Listrik di Kabupaten Lampung Selatan...}

located adjacent to Bandar Lampung City. Jati Agung has access to Trans-Sumatera Highway which is indicated by the entrance and exit gate of the highway. Moreover, there is a new educational activity, Institut Teknologi Sumatera, and a governmental activity called Kota Baru. As a potential fast-growing district in Lampung Province, Jati Agung needs a community resilience strategy to cope with the current threat of electricity crisis in Jati Agung, South Lampung. This research aims to map the community resilience dimension to the threat of electricity crisis in Jati Agung, South Lampung based on the community perception. In this study, the community is represented by household units which are located in the study area. This study is expected to examine how resilient of each dimension about the electricity crisis in the study area. The community resilience dimension has four categories, i.e. 1) Health and Wellbeing, 2) Economy and Society, 3) Infrastructure and Environment, and 4) Leadership and Strategy. This research conducts a descriptive statistics analysis by using a Likert scale to assess community resilience for each driving factor in each dimension. The result shows that "Leadership and Strategy" dimension has the lowest score and classified as a "poor resilience" dimension.

Keywords: community resilience, electricity, energy crisis, Lampung, Likert scaling

\section{Pendahuluan}

Ketahanan kota (city resilience) saat ini menjadi topik hangat dalam pembangunan kota di dunia baik di negara maju maupun negara berkembang. Upaya perwujudan kota yang berketahanan tertuang jelas dalam Sustainable Development Goals(SGDs) yaitu pada tujuan ke-11, "Make Cities Inclusive, Safe, Resilient, and Sustainable". Community and Regional Resilience Institute (2013) menegaskan makna "berketahanan" dalam kota berketahanan adalah kota yang dihuni oleh penduduk yang memiliki kapasitas dan kemampuan untuk bangkit dari ancaman dan permasalahan yang dihadapi bersama. Perumusan tujuan ini dilatarbelakangi oleh kecenderungan lebih dari setengah populasi dunia akan tinggal di wilayah perkotaan di masa yang akan datang sehingga meningkatkan konsekuensi bertambahnya permasalahan di kawasan perkotaan setiap tahunnya meliputi polusi, kemiskinan, aksesibilitas terhadap energi, perumahan, transportasi dan permasalahan lainnya.

Jumlah populasi penduduk di Indonesia menempati urutan keempat terbesar di dunia (Kementerian ESDM, 2015). Di tahun 2010, data jumlah penduduk di Indonesia menurut Badan Pusat Statistik (BPS) mencapai 237,5 juta jiwa. Besarnya populasi penduduk di Indonesia membawa konsekuensi akan besarnya kebutuhan dasar salah satunya adalah kebutuhan energi (Kementerian ESDM, 2015). Penggunaan energi sangat penting bagi kelangsungan hidup manusia, karena seluruh aktivitas manusia membutuhkan energi seperti produksi industri, transportasi, hingga kegiatan rumah tangga. Sebagai salah satu negara berkembang, Indonesia telah memiliki rencana dan strategi terhadap ancam an krisis energi khususnya di kawasan perkotaan. Hal ini dilatarbelakangi oleh tingginya kebutuhan konsumsi energi di kawasan perkotaan khususnya Indonesia bagian barat yang terdiri dari Jawa-Bali, yaitu sebanyak $77 \%$ dan Sumatera yaitu 14\% dari total konsumsi energi di Indonesia (BPPT, 2014). Dari sektor ketenagalistrikan, saat ini pembangkit listrik di Indonesia masih didominasi oleh penggunaan bahan bakar fosil salah satunya adalah Sumatera yang masih menggunakan bahan bakar fosil berupa minyak bumi sebagai sumber pembangkit listriknya. Beberapa provinsi yang ada di Pulau Sumatera seperti Aceh, Sumatera Utara, Sumatera Barat, Riau, Jambi, Sumatera Selatan, Bengkulu dan Lampung mengalami kekurangan ketersediaan (defisit) daya listrik, sedangkan provinsi lainnya seperti Batam, Bangka dan Belitung mengalami kondisi siaga. Jadi, dapat disimpulkan ketersediaan daya listrik Sumatera masih defisit sehingga belum mampu memenuhi kebutuhan energi listrik masyarakat. 
Provinsi Lampung merupakan salah satu provinsi yang terdapat di Pulau Sumatera, Indonesia. Provinsi Lampung menghadapi permasalahan krisis energi akibat terjadinya defisit daya listrik di Provinsi Lampung yang mencapai 200 Megawatt (MW), padahal pertumbuhan ekonomi Indonesia yang rata-rata mencapai $5 \%$ pertahun diperlukan tambahan listrik sebesar 5.000 MW pertahun, sehingga defisit energi listrik di Sumatera khususnya Provinsi Lampung dapat mengganggu perekonomian setempat. Pemadaman aliran listrik di beberapa wilayah Provinsi Lampung pun terus terjadi di tahun 2017 (Hermawan, 2016). Berkurangnya daya listrik yang terjadi diakibatkan oleh kinerja Pembangkit Listrik Tenaga Uap (PLTU) Sebalang yang belum bekerja maksimal dan empat unit lainnya di Tarahan yang bermasalah. Kondisi tersebut secara langsung mengganggu aktivitas sehari-hari. Dalam konteks pembangunan wilayah dan kota, krisis energi khususnya krisis energi listrik di suatu daerah secara langsung dapat menghambat berkembangnya aktivitas di daerah tersebut dan sekitarnya. Krisis energi listrik yang berimplikasi pada peningkatan pemadaman listrik pada waktu-waktu tertentu, menghambat berbagai aktivitas di antaranya aktivitas kesehatan, pendidikan, perdagangan, dan jasa.

Permasalahan krisis energi dan keberlanjutan pemenuhan energi menjadi tantangan utama bagi pelaku pembangunan di Provinsi Lampung supaya pembangunan wilayah dan kota di Provinsi Lampung terus berjalan. Seluruh pelaku pembangunan di Provinsi Lampung berupaya memenuhi kebutuhan energi listrik. Saat ini upaya pemenuhan kebutuhan listrik di Provinsi Lampung dilakukan oleh pemerintah dengan menambah pasokan daya listrik mencapai 215 MW di tahun 2016 yang dihasilkan dari Pembangkit Listrik Tenaga Mesin Gas (PLTMG) New Tarahan, PLTMG Sutami, Mobile Power Plant PLTMG, dan Pembangkit Listrik Tenaga Panas Bumi (PLTP) Ulubelu (Hermawan, 2016). Sejalan dengan hal tersebut, upaya pemenuhan listrik juga dilakukan secara mandiri oleh masyarakat dengan bimbingan pemerintah, akademisi dan pihak swasta melalui berbagai program, salah satunya adalah Program Bina Desa Mandiri Energi yang berlokasi di Kabupaten Lampung Selatan tepatnya di Desa Tajimalela dan Desa Sidomukti di Kecamatan Kalianda dan Desa Sidomukti di Kecamatan Tanjungsari.

Program Bina Desa Mandiri di Provinsi Lampung merupakan upaya yang cukup strategis dan sejalan dengan tujuan ke-11 Sustainable Development Goals (SDGs) yaitu mewujudkan kota dan kawasan permukiman yang memiliki konsep inklusif, aman, berketahanan dan berkelanjutan di tahun 2030. Program Bina Desa Mandiri dianggap mampu menjawab tantangan krisis energi di Provinsi Lampung. Selain itu, program ini juga dianggap mampu meningkatkan daya adaptasi masyarakat terhadap tantangan pemenuhan kebutuhan listriknya.

Sebagai salah satu kecamatan yang ada di Kabupaten Lampung Selatan, Kecamatan Jati Agung berlokasi dekat dengan Kota Bandar Lampung. Di Kecamatan Jati Agung terdapat akses pintu masuk dan keluar jalan bebas hambatan (tol) Trans Sumatera. Selain itu, di Kecamatan Jati Agung terdapat kawasan pemerintahan dan pendidikan baru yang ditandai dengan adanya pembangunan Kota Baru dan Institut Teknologi Sumatera (ITERA) yang merupakan perguruan tinggi negeri baru yang berdiri pada 6 Oktober 2014. Keberadaan ITERA berpotensi memicu pertumbuhan aktivitas pendukung dari aktivitas pendidikan lainnya seperti aktivitas permukiman, aktivitas perdagangan dan jasa dan aktivitas lainnya. Secara keruangan, Kecamatan Jati Agung memiliki kecenderungan peningkatan alih fungsi lahan pertanian menjadi nonpertanian sebagai akibat adanya peningkatan aktivitas nonpertanian. Oleh karena itu, sebagai daerah yang berpotensi cepat tumbuh, Kecamatan Jati Agung memerlukan strategi ketahanan yang cukup terhadap ancaman krisis energi yang saat ini terjadi.

Penelitian ini bertujuan untuk mengkaji ketahanan masyarakat dalam menghadapi ancaman krisis energi listrik di Provinsi Lampung. Peneliti memilih Kecamatan Jati Agung, Kabupaten Lampung Selatan sebagai studi kasus untuk mengkaji bagaimana ketahanan 


\section{Ketahanan Masyarakatterhadap Ancaman Krisis EnergiListrik di Kabupaten LampungSelatan...}

masyarakat terhadap ancaman krisis energi listrik. Sasaran dari tujuan tersebut adalah sebagai berikut:

a. Identifikasi karakteristik Kecamatan Jati Agung, Kabupaten Lampung Selatan yang dikategorikan ke dalam empat dimensi ketahanan, yaitu:

- Kesehatan dan kesejahteraan

- Ekonomi dan sosial

- Lingkungan dan infrastruktur

- Kepemimpinan dan strategi

b. Analisis ketahanan masyarakat di Kecamatan Jati Agung, Kabupaten Lampung Selatan terhadap ancaman krisis energi listrik.

\section{Konsep Ketahanan Masyarakat}

Terminologi ketahanan (resilience) pertama kali muncul sebelum tahun 1854. Saat itu, istilah ketahanan digunakan dalam kesusasteraan, hukum, dan tata negara (Alexander, 2013). Saat ini, istilah ketahanan atau biasa disebut dengan "resilience" digunakan dalam beragam disiplin ilmu sehingga berimplikasi pada keragaman definisi ketahanan sesuai dengan bidang ilmu kajian tersebut. Pada bidang ilmu ekologi, ketahanan (resilience) adalah sebuah ukuran keuletan sistem dan kemampuannya untuk menyerap perubahan dan gangguan dan masih memelihara hubungan yang sama antara populasi atau kondisi variabel-variabel (Holling, 1973; Speranza, Wiesmann, \& Rist, 2014). Pada bidang geografi manusia, ketahanan sosial (social resilience) adalah kemampuan sekelompok atau komunitas untuk menanggulangi tekanan dan gangguan eksternal sebagai sebuah hasil dari perubahan sosial, politik dan lingkungan (Adger, 2000). Sementara itu, pada bidang ilmu kajian spesifik sistem sosial-ekologi, ketahanan sosial-ekologi (social-ecology resilience) diinterpretasi oleh Carpenter, Walker, Anderies, \& Abel (2001) \& Folke (2006), sebagai:

1. Sejumlah gangguan pada suatu sistem untuk dapat menyerap gangguan dan kembali pada kondisi semula.

2. Derajat suatu sistem untuk mampu mengorganisasi diri.

3. Derajat suatu sistem dalam membangun dan meningkatkan kapasitas untuk belajar dan beradaptasi.

Hal yang paling mendasar dalam memahami konsep ketahanan adalah proses dari terbentuknya ketahanan itu sendiri. Sebagaimana yang dijelaskan oleh Luthar dan Cicchetti (dalam Buikstra et al. 2010) yang menekankan bahwa proses ketahanan ini dititikberatkan pada upaya adaptasi ketika berada pada situasi sulit dan bangkit kembali kepada kondisi yang lebih baik. Sebagai pelaku pembangunan, keberadaan manusia menjadi pengaruh sekaligus yang terpengaruh dari kondisi lingkungan sekitar baik lingkungan fisik maupun nonfisik. Dalam konteks pembangunan wilayah dan kota, ketahanan masyarakat sangat berperan signifikan untuk memperkuat masyarakat menghadapi dinamika pembangunan khususnya permasalahan yang datang baik dari dalam maupun luar wilayah. Buikstra et al. (2010) menambahkan bahwa ketahanan masyarakat di suatu wilayah dipengaruhi oleh modal masyarakat (community capitals) yang terdiri dari manusia dan materi lainnya seperti modal sosial, modal budaya, modal manusia, modal politik, modal sumber daya alam, modal finansial, dan modal infrastruktur. Pemahaman mengenai konsep ketahanan ini dikembangkan dan didefinisikan kembali oleh Rockefeller Foundation and ISET (2010), sebagai kemampuan bertahan sebuah sistem dari tekanan (stresses) dan kejutan (shocks) serta kemampuan sebuah sistem untuk memelihara fungsinya agar sistem tersebut terus berjalan.

Di tahun 2014, dalam kerangka strategi ketahanan kota (city resilience strategy), Arup \& The Rockefeller Foundation (2014) menjelaskan bahwa ketahanan masyarakat 
sangat berpengaruh terhadap ketahanan kota itu sendiri. Ketahanan masyarakat dapat mempengaruhi dan dipengaruhi oleh empat dimensi yaitu:

1. Kesehatan dan kesejahteraan (health and wellbeing), yang meliputi tiga faktor penggerak (driving factors) yaitu:

- upaya pemenuhan kebutuhan dasar;

- kesempatan kerja; dan

- layanan kesehatan masyarakat.

2. Ekonomi dan sosial masyarakat (economy and society), yang meliputi tiga faktor penggerak yaitu:

- keterlibatan dan keaktifan warga dalam kehidupan bermasyarakat;

- kestabilan sosial, keamanan lingkungan; dan

- ekonomi perkotaan.

3. Lingkungan dan infrastruktur (infrastructure and environment), yang meliputi tiga faktor penggerak yaitu:

- sumber daya alam dan infrastruktur;

- layanan infrastruktur dan lingkungan (critical services); dan

- komunikasi dan pergerakan masyarakat.

4. Kepemimpinan dan strategi (leadership and strategy), yang meliputi tiga faktor penggerak yaitu:

- kepemimpinan dan manajemen yang efektif;

- keterlibatan pemangku kepentingan dari berbagai latar belakang; dan

- rencana pembangunan jangka panjang yang terintegrasi.

Konsep ketahanan masyarakat dalam hal ini adalah ketahanan rumah tangga yang mencakup beberapa indikator. Marschke \& Berkes (2006) mengidentifikasi strategi-strategi masyarakat membangun ketahanan mata pencaharian. Strategi-strategi tersebut meliputi diversifikasi, belajar untuk hidup dengan perubahan dan ketidakpastian, terus belajar dan beradaptasi, menciptakan kesempatan untuk mengorganisasi diri, dan kesejahteraan. Nyamwanza (2012) mengungkapkan indikator (surrogates) dan proses utama ketahanan mata pencaharian. Indikator-indikator tersebut yaitu: 1) pembelajaran untuk hidup dengan perubahan dan ketidakpastian; 2) pemeliharaan proses pembelajaran dan pengadaptasian; 3) pengorganisasian diri; 4) kesejahteraan; dan 5) keberlanjutan (Nyamwanza, 2012).

Berangkat dari konsep ketahanan yang dikembangkan Rockefeller Foundation and ISET (2010) dan indikator ketahanan rumah tangga yang dijabarkan oleh Marschke \& Berkes (2006) dan Nyamwanza (2012), studi ini mengembangkan dimensi ketahanan pada faktor penggerak masing-masing dimensi untuk mengkaji ketahanan masyarakat di wilayah studi terhadap ancaman krisis energi yang diindikasikan dengan adanya frekuensi kejadian pemadaman listrik di wilayah studi. Berikut faktor-faktor penggerak yang dikembangkan dalam studi ini untuk mengkaji ketahanan masyarakat terhadap krisis energi listrik di wilayah studi:

1. Kesehatan dan kesejahteraan (health and wellbeing)

- ketahanan aktivitas pemenuhan kebutuhan sehari-hari responden (misalnya: bekerja, bertani, dan lain-lain) terhadap kejadian pemadaman listrik;

- kestabilan pendapatan responden terhadap kejadian pemadaman listrik; dan

- kualitas layanan kesehatan yang diterima responden terhadap kejadian pemadaman listrik.

2. Ekonomi dan sosial masyarakat (economy and society)

- ketahanan aktivitas responden dalam bersosialisasi terhadap kejadian pemadaman listrik;

- kestabilan sosial dan keamanan lingkungan terhadap kejadian pemadaman listrik; dan 
- kestabilan perekonomian di lingkungan tempat tinggal responden terhadap kejadian pemadaman listrik.

3. Lingkungan dan infrastruktur (infrastructure and environment)

- kualitas layanan dasar air bersih di tempat tinggal responden terhadap kejadian pemadaman listrik;

- kualitas layanan dasar telekomunikasi di tempat tinggal responden terhadap kejadian pemadaman listrik; dan

- kualitas layanan penerangan jalan di tempat tinggal responden terhadap kejadian pemadaman listrik.

4. Kepemimpinan dan strategi (leadership and strategy)

- sikap tanggap pemimpin lingkungan tempat tinggal responden terhadap kejadian pemadaman listrik;

- ketersediaan program yang diinisiasi pemimpin di tempat tinggal responden terkait upaya penanganan pemadaman listrik; dan

- keberlanjutan program yang diterapkan pemimpin di tempat tinggal responden terkait upaya penanganan pemadaman listrik.

\section{Metode Penelitian}

Lokasi penelitian di Kabupaten Lampung Selatan, tepatnya Kecamatan Jati Agung. Pengambilan data dilakukan secara menyuluruh di seluruh desa di Kecamatan Jati Agung, yang terdiri dari 21 desa meliputi:

1 Way Hui

2 Jati Mulyo

3 Banjar Agung

4 Gedung Harapan

5 Gedung Agung

6 Margo Mulyo

7 Sidodadi Asri
8 Purwotani

9 Sumberjaya

10 Margo Dadi

11 Margo Lestari

12 Marga Agung

13 Marga Kaya

14 Sinar Rejeki
15 Sidoharjo

16 Rejomulyo

17 Karang Anyar

18 Fajar Baru

19 Karang Sari

20 Karang Rejo

21 Margo Rejo

Sebagaimana yang telah disebutkan pada pendahuluan, tujuan studi ini adalah mengkaji dimensi ketahanan terhadap ancaman krisis energi listrik sehingga hasil kajian dapat digunakan sebagai bahan pertimbangan atau input untuk menyusun strategi ketahanan masyarakat terhadap ancaman energi listrik. Masyarakat dalam hal ini adalah rumah tangga. Dalam studi ini dilakukan pengkajian mengenai ketahanan rumah tangga terhadap ancaman krisis energi listrik yang ditinjau dari kejadian frekuensi pemadaman listrik di wilayah studi. Pada studi ini dikaji bagaimana rumah tangga di wilayah studi merespon, memulihkan kembali, dan belajar dari pengalaman krisis energi listrik di wilayah studi. Konsep ketahanan masyarakat yang dikaji pada studi ini merujuk pada Nyamwanza (2012) yang mendefinisikan ketahanan mata pencaharian (livelihood resilience) sebagai sebuah proses terkait kapasitas rumah tangga dan komunitas untuk merespon, memulihkan kembali, dan belajar dari perubahan dan gangguan, dan untuk mengembalikan kembali, memperbarui dan memperkuat kembali penghasilannya dan pola mata pencaharian yang diganggu oleh perubahan dan tantangan di dalam lingkungan sosial dan fisik. Sementara itu, Tanner et al. (2015) mendefinisikan ketahanan mata pencaharian sebagai kapasitas semua orang lintas generasi untuk meneruskan dan memperbaiki peluang mata pencahariannya dan kesejahteraannya meskipun terganggu secara politik, sosial, ekonomi dan lingkungan. Oleh karena itu, objek penelitian studi ini adalah ketahanan rumah tangga masyarakat Kecamatan Jati Agung, Kabupaten Lampung Selatan . 
Mengacu data dari BPS Kabupaten Lampung Selatan 2016, jumlah penduduk di Kecamatan Jati Agung sebesar 110.176 jiwa. Adapun jumlah rumah tangga di Kec amatan Jati Agung diasumsikan satu rumah tangga beranggotakan empat jiwa sehingga jumlah rumah tangga di Kecamatan Jati Agung sebesar 27.544 jiwa. Jumlah rumah tangga di Kecamatan Jati Agung terbilang cukup besar sehingga tidak memungkinkan untuk melakukan sensus dalam waktu 8 (delapan) bulan. Oleh karena itu, peneliti menggunakan sampel dalam studi ini. Berikut ini merupakan perhitungan sampel dengan menggunakan rumus Isaac dan Michael (Sugiyono, 2008) dalam studi ini, yaitu:

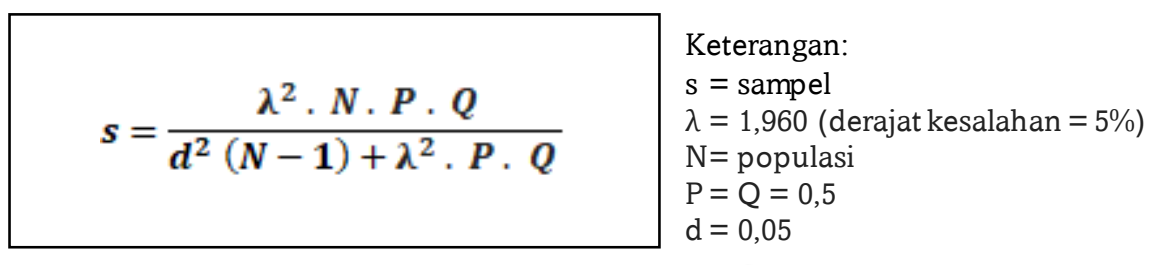

$$
\begin{aligned}
& s=\frac{(1,960)^{2} \times 27.544 \times 0,5 \times 0,5}{0,05^{2}(27.544-1)+1,960^{2} \times 0,5 \times 0,5} \\
& s=\frac{26.453,26}{68,86+0,96} \\
& s=378,87 \text { atau setara dengan } 379 \text { rumah tangga }
\end{aligned}
$$

Sesuai dengan hasil perhitungan sampel sebanyak 379 rumah tangga, jumlah sampel masih terlalu besar. Oleh karena itu, peneliti melakukan iterasi kedua untuk menghitung sampel dengan menggunakan proporsi dari Nomogram Harry King untuk mengeliminasi ukuran sampel. Dengan menggunakan confident interval sebesar 95\%, multiplier factor yang diperoleh sebesar 1,195 (Soetomo, 2008). Hasil dari Nomogram menunjukkan bahwa proporsi yang tepat untuk mengeliminasi ukuran sampel sebesar 38\%, sehingga ukuran sampel akhir sebagai berikut:

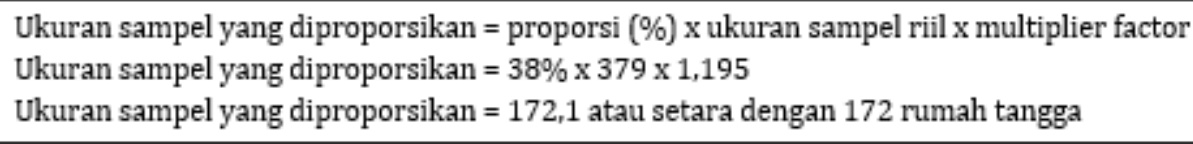

Adapun distribusi sampel dilakukan dengan menggunakan metode simple random sampling. Metode ini diterapkan dengan tujuan memperoleh data yang objektif sehingga mampu menggambarkan kondisi yang sebenarnya. Pengambilan data primer ini dilakukan karena tidak banyak data yang tersedia terkait dengan ketahanan masyarakat terhadap gangguan baik internal maupun eksternal. Sebagaimana yang dijelaskan oleh Goulden, Adger, Allison, \& Conway (2013), bahwa hampir di setiap daerah memiliki keterbatasan data yang menjelaskan mengenai kemampuan beradaptasi populasi penduduknya untuk bertahan dari perubahan sosial dan ekologi yang dinamis. Oleh karena itu, untuk mendukung tercapainya pengukuran atau survei yang objektif, sebaran atau distribusi sampel per desa ditentukan sesuai besaran proporsi jumlah penduduk per desa di Kecamatan Jati Agung. Distribusi sebaran sampel untuk masing-masing desa, dapat dilihat pada Tabel 1. 
Tabel 1. Distribusi Sampel Penelitian

\begin{tabular}{clccc}
\hline No & \multicolumn{1}{c}{ Desa } & Proporsi $(\boldsymbol{\%})$ & $\begin{array}{c}\text { Hasil Proporsi } \\
\text { Sampel }\end{array}$ & $\begin{array}{c}\text { Jumlah Sampel } \\
\text { (Pembulatan) }\end{array}$ \\
\hline 1 & Way Hui & 11 & 18.92 & 19 \\
2 & Jati Mulyo & 14 & 24.08 & 24 \\
\hline 3 & Banjar Agung & 2 & 3.44 & 3 \\
4 & Gedung Harapan & 1 & 1.72 & 2 \\
5 & Gedung Agung & 1 & 1.72 & 2 \\
6 & Margo Mulyo & 2 & 3.44 & 3 \\
7 & Sidodadi Asri & 5 & 8.60 & 3 \\
8 & Purwotani & 2 & 3.44 & 7 \\
9 & Sumberjaya & 4 & 6.88 & 5 \\
10 & Margo Dadi & 3 & 5.16 & 5 \\
11 & Margo Lestari & 3 & 5.16 & 7 \\
12 & Marga Agung & 4 & 6.88 & 5 \\
13 & Marga Kaya & 3 & 5.16 & 5 \\
14 & Sinar Rejeki & 7 & 12.04 & 9 \\
15 & Sidoharjo & 3 & 5.16 & 28 \\
16 & Rejomulyo & 5 & 8.60 & 9 \\
17 & Karang Anyar & 16 & 27.50 & 9 \\
18 & Fajar Baru & 5 & 8.60 & 9 \\
19 & Karang Sari & 5 & 8.60 & 3 \\
20 & Karang Rejo & 5 & 8.60 & \\
21 & Margo Rejo & 2 & 3.44 & \\
\hline
\end{tabular}

Sumber: Analisis Peneliti, 2017

\section{Karakteristik Kecamatan Jati Agung Kabupaten Lampung Selatan}

Kecamatan Jati Agung memiliki 21 desa dengan luas wilayah $164,47 \mathrm{~km}^{2}$. Batas administrasi Kecamatan Jati Agung di sebelah utara berbatasan dengan Kabupaten Lampung Timur dan sebelah selatan berbatasan dengan Kota Bandar Lampung dan Kecamatan Tanjung Bintang. Selanjutnya, di bagian barat berbatasan dengan Kecamatan Natar dan sebelah timur berbatasan dengan Kabupaten Lampung Timur (BPS Kabupaten Lampung Selatan, 2016). Dilihat dari tingkat kesejahteraan penduduknya, persentase keluarga sejahtera di wilayah studi masih mendominasi yaitu sebanyak $32 \%$ dari total penduduk (BPS Kabupaten Lampung Selatan, 2016). Adapun mayoritas pekerjaan masyarakat di wilayah studi sebagian besar bekerja sebagai peternak dan petani (BPS Kabupaten Lampung Selatan, 2016).

Berkaitan dengan akses terhadap listrik, cakupan akses penduduk terhadap layanan listrik oleh Perusahaan Listrik Negara (PLN) mencapai 100\% dengan daya listrik terpasang di Kecamatan Jati Agung kurang lebih sebesar 65\% dari total penduduk yang memasang daya listrik sebesar 900 Volt (BPS Kabupaten Lampung Selatan, 2016). Di Kecamatan Jati Agung, umumnya responden menggunakan energi listrik untuk aktivitas rumah tangga. Hal ini dapat dilihat dari hasil kuesioner yang menunjukkan bahwa $72 \%$ responden menggunakan energi listrik untuk menunjang aktivitas rumah tangga dan $26 \%$ responden menggunakan energi listrik untuk rumah tangga dan komersial secara bersamaan.

Krisis energi listrik di Kecamatan Jati Agung diakibatkan adanya keterbatasan pasokan yang kemudian menyebabkan pemadaman listrik secara periodik. Berdasarkan kuesioner yang diberikan kepada 172 responden, Kecamatan Jati Agung mengalami pemadaman listrik kurang lebih sebanyak dua kali dalam sebulan. Terjadinya pemadaman listrik yang periodik umumnya memiliki pengaruh terhadap kinerja layanan infrastruktur dasar di antaranya telekomunikasi dan air bersih. Berdasarkan hasil kuesioner, layanan telekomunikasi di Kecamatan Jati Agung didominasi oleh layanan telepon seluler. Hal ini dapat dilihat dari keberadaan pemancar telepon genggam yang ada di Kecamatan Jati 
Agung sebanyak 16 unit yang tersebar di Desa Way Hui sebanyak 1 unit, Jati Mulyo sebanyak 5 unit, Margo Lestari sebanyak 1 unit, Marga Agung sebanyak 1 unit, Sinar Rejeki sebanyak 1 unit, Rejomulyo 1 unit, Karang Anyar sebanyak 5 unit dan Karang Sari sebanyak 1 unit (BPS Kabupaten Lampung Selatan, 2016). Untuk layanan air bersih, terdapat perusahaan air bersih di Kecamatan Jati Agung sebanyak 1 unit yaitu PDAM Tirta Jasa Hajimena Way Kandis. Kebutuhan air bersih di Kecamatan Jati Agung tidak hanya dipenuhi dengan jaringan air bersih tetapi juga nonjaringan yaitu sumur bor yang terpasang di rumah penduduk Kecamatan Jati Agung.

Selain infrastruktur fisik, karakteristik wilayah studi juga dipengaruhi oleh arahan kebijakan pembangunan yang ada di wilayah tersebut. Dalam konteks krisis energi listrik, perlu dilakukan upaya-upaya sebagai bentuk tanggapan terhadap permasalahan publik. Sistem energi merupakan produk hasil satu kesatuan berbagai upaya dari faktor sosial ekonomi masyarakat, ketersediaan sumber energi, tantangan pengelolaan, kapasitas teknologi pengelolaan dan distribusi, dan arahan kebijakan pengelolaan dan distribusinya (O’Brien \& Hope, 2010). Oleh karena itu, keberadaan kebijakan penting untuk mengantisipasi pembangunan terhadap ancaman krisis energi listrik yang diakibatkan kurangnya pasokan listrik. Berdasarkan dokumen perencanaan pembangunan wilayah studi, arahan kebijakan dalam rangka menghadapi krisis energi listrik di wilayah studi dilakukan melalui tiga arahan yaitu: 1) meningkatkan kapasitas listrik di seluruh wilayah Kabupaten Lampung Selatan melalui pemanfaatan energi panas bumi; 2) pemanfaatan energi panas bumi Gunung Rajabasa sebagai sumber energi listrik; dan 3) pengembangan jaringan listrik.

\section{Analisis Ketahanan Masyarakat di Kecamatan Jati Agung terhadap Ancaman Krisis Energi}

Setelah mengetahui karakter penggunaan energi listrik dan gangguannya di Kecamatan Jati Agung, kemudian dilakukan identifikasi karakter ketahanan masyarakat Kecamatan Jati Agung terkait ancaman krisis energi yang dinilai dari empat dimensi yang telah dikembangkan. Analisis kerentanan area dimensi dilakukan dengan menggunakan teknik skoring terhadap keempat dimensi. Responden memberikan skor pada keempat dimensi ketahanan untuk menentukan dimensi mana yang paling rentan akibat adanya krisis energi di Kecamatan Jati Agung. Penilaian akan diberikan oleh responden dengan memberikan skor 1-4 untuk masing-masing faktor penggerak dimensi ketahanan. Responden menilai faktor mana saja yang paling rentan akibat adanya krisis energi di Kecamatan Jati Agung. Adapun penilaian yang diberikan mengacu pada kriteria sebagai berikut:

Skor $1=$ Sangat terganggu akibat adanya pemadaman listrik (sangat rentan)

Skor $2=$ Terganggu akibat adanya pemadaman listrik (rentan)

Skor $3=$ Cukup terganggu akibat adanya pemadaman listrik (cukup rentan)

Skor $4=$ Tidak terganggu akibat adanya pemadaman listrik (tidak rentan) Tabel 2.

Daftar isian yang dirancang untuk diberikan kepada responden dapat dilihat pada

Tabel 2. Pemetaan Kerentanan Dimensi terhadap Krisis Energi Listrik

\begin{tabular}{|c|c|c|c|c|}
\hline \multirow{2}{*}{$\begin{array}{c}\text { Dimensi } \\
\text { Kesehatan \& } \\
\text { kesejahteraan }\end{array}$} & Faktor Penggerak & \multicolumn{3}{|c|}{ Penilaian Kerentanan } \\
\hline & $\begin{array}{l}\text { Aktivitas memenuhi kebutuhan dasar: } \\
\text { sandang, pangan dan papan }\end{array}$ & Tidak rentan & 4321 & Sangat rentan \\
\hline & Kestabilan pendapatan responden & Tidak rentan & 4321 & Sangat rentan \\
\hline & $\begin{array}{l}\text { Aktivitas layanan kesehatan yang } \\
\text { diterima responden }\end{array}$ & Tidak rentan & 4321 & Sangat rentan \\
\hline Ekonomi \& & Aktivitas responden dalam kehidupan & Tidak rentan & 4321 & Sangat rentan \\
\hline
\end{tabular}




\section{Ketahanan Masyarakat terhadap Ancaman Krisis EnergiListrik di Kabupaten Lampung Selatan...}

\begin{tabular}{|c|c|c|c|c|}
\hline Dimensi & Faktor Penggerak & \multicolumn{3}{|c|}{ Penilaian Kerentanan } \\
\hline \multirow{3}{*}{$\begin{array}{l}\text { sosial } \\
\text { masyarakat }\end{array}$} & bermasyarakat & & & \\
\hline & $\begin{array}{l}\text { Kestabilan sosial/ keamanan di } \\
\text { lingkungan responden }\end{array}$ & Tidak rentan & $\begin{array}{lll}432 & 21\end{array}$ & Sangat rentan \\
\hline & $\begin{array}{l}\text { Kestabilan aktivitas ekonomi (bekerja) } \\
\text { di lingkungan responden }\end{array}$ & Tidak rentan & $\begin{array}{lll}432 & 21\end{array}$ & Sangat rentan \\
\hline \multirow[t]{3}{*}{$\begin{array}{l}\text { Lingkungan \& } \\
\text { infrastruktur }\end{array}$} & $\begin{array}{l}\text { Aktivitas pelayanan infrastruktur dasar } \\
\text { seperti air bersih di tempat tinggal } \\
\text { responden }\end{array}$ & Tidak rentan & 4321 & Sangat rentan \\
\hline & $\begin{array}{l}\text { Aktivitas pelayanan infrastruktur } \\
\text { komunikasi di tempat tinggal responden }\end{array}$ & Tidak rentan & $\begin{array}{llll}43 & 2 & 1\end{array}$ & Sangat rentan \\
\hline & $\begin{array}{l}\text { Aktivitas pelayanan infrastruktur } \\
\text { transportasi(penerangan jalan) di } \\
\text { tempat tinggal responden }\end{array}$ & Tidak rentan & $\begin{array}{lll}432 & 21\end{array}$ & Sangat rentan \\
\hline \multirow[t]{3}{*}{$\begin{array}{l}\text { Kepemimpinan } \\
\& \text { Strategi }\end{array}$} & $\begin{array}{l}\text { Sikap tanggap pemimpin lingkungan } \\
\text { tempat tinggal anda (Ketua } \\
\text { RT/RW/Kades) }\end{array}$ & Tidak rentan & $\begin{array}{lll}4 & 32 & 1\end{array}$ & Sangat rentan \\
\hline & $\begin{array}{l}\text { Program yang diterapkan oleh } \\
\text { pemimpin lingkungan tempat tinggal } \\
\text { anda dalam menghadapi pemadaman } \\
\text { listrik }\end{array}$ & Tidak rentan & 43221 & Sangat rentan \\
\hline & $\begin{array}{l}\text { Keberlanjutan program penanganan } \\
\text { pemadaman listrik di lingkungan anda }\end{array}$ & Tidak rentan & $\begin{array}{lll}432 & 21\end{array}$ & Sangat rentan \\
\hline
\end{tabular}

Perhitungan hasil skoring ketahanan masyarakat di Kecamatan Jati Agung terhadap ancaman krisis energi diperoleh dengan menjumlahkan seluruh skor responden (penilaian kerentanan) pada masing-masing dimensi dan masing-masing faktor penggerak sehingga didapatkan identifikasi ketahanan masyarakat di Kecamatan Jati Agung. Adapun pengelompokan/klasifikasi ketahanan dimensi ditentukan dengan acuan skoring sebagai berikut:

$$
\begin{array}{ll}
0-516 & \text { : sangat tidak berketahanan } \\
517-1.032 & \text { : tidak berketahanan } \\
1.033-1.548 & \text { : cukup berketahanan } \\
1.549-2.064 & \text { : berketahanan }
\end{array}
$$

Pengelompokan/klasifikasi ketahanan faktor penggerak ditentukan dengan acuan skoring sebagai berikut:

$$
\begin{array}{ll}
0-172 & : \text { sangat tidak berketahanan } \\
173-344 & \text { : tidak berketahanan } \\
345-516 & \text { : cukup berketahanan } \\
516-688 & \text { : berketahanan }
\end{array}
$$

\section{Kesehatan dan Kesejahteraan}

Secara umum, ketahanan dimensi kesehatan dan kesejahteraan masyarakat di Kecamatan Jati Agung terhadap ancaman krisis listrik mendapat skor 1.410 dari 2.064 sehingga dimensi ini termasuk dalam kategori "cukup berketahanan" terhadap ancaman krisis listrik (Gambar 1). 


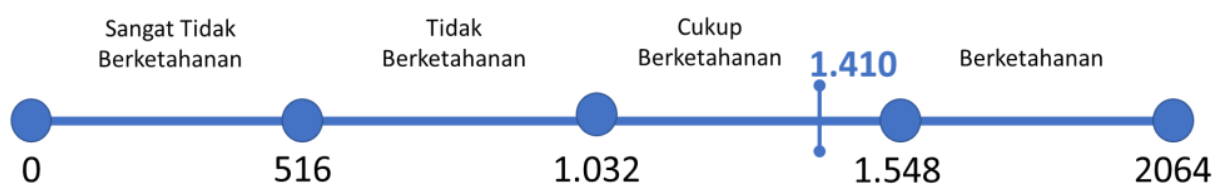

Sumber:Analsis Peneliti, 2017

Gambar 1. Ketahanan Dimensi Kesehatan dan Kesejahteraan Masyarakat Kecamatan Jati Agung

Lebih detail, dimensi kesehatan dan kesejahteraan memiliki tiga faktor penggerak dan ketiganya memiliki karakteristik ketahanan yang berbeda yang dapat dilihat pada Gambar 2.

a. Aktivitas pemenuhan kebutuhan dasar (sandang, pangan dan papan)

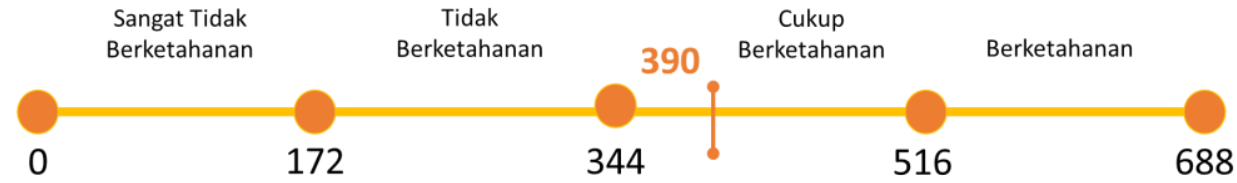

b. Kestabilan pendapatan masyarakat

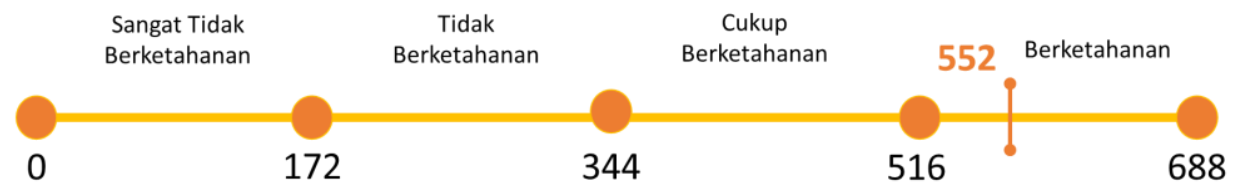

c. Aktivitas pelayanan kesehatan untuk masyarakat

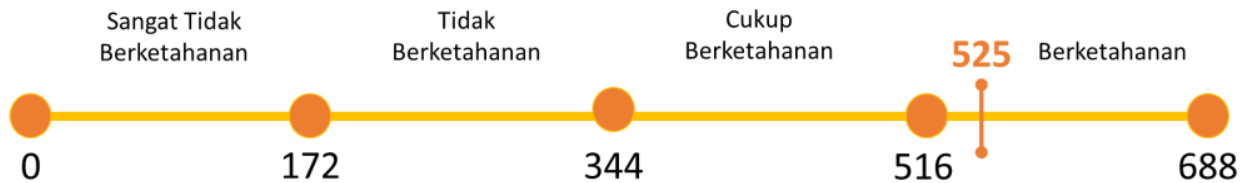

Sumber: Analisis Peneliti, 2017

\section{Gambar 2. Ketahanan Faktor Penggerak Dimensi Kesehatan dan Kesejahteraan Masyarakat Kecamatan Jati Agung terhadap Ancaman Krisis Listrik}

Berdasarkan hasil penilaian responden, ketahanan dimensi kesehatan dan kesejahteraan masyarakat Kecamatan Jati Agung dinilai masih cukup berketahanan. Meskipun terdapat dua faktor penggerak yang masuk dalam kategori "berketahanan" yaitu pendapatan masyarakat dan aktivitas pelayanan kesehatan untuk masyarakat. Kondisi ini disebabkan pekerjaan responden yang mayoritas merupakan ibu rumah tangga tidak terganggu dengan adanya pemadaman listrik. Selain itu, pelayanan kesehatan untuk masyarakat di Kecamatan Jati Agung dinilai berketahanan terhadap ancaman krisis listrik. Hasil wawancara terbuka dengan warga di Kecamatan Jati Agung menyebutkan bahwa 


\section{Ketahanan Masyarakat terhadap Ancaman Krisis Energi Listrik di Kabupaten Lampung Selatan...}

hampir seluruh layanan kesehatan sudah dilengkapi genset sehingga adanya gangguan listrik yang terjadi tidak mengganggu layanan yang diberikan.

\section{Ekonomi dan Sosial Masyarakat}

Secara umum, ketahanan dimensi ekonomi dan sosial masyarakat di Kecamatan Jati Agung terhadap ancaman krisis listrik mendapat skor 1.603 dari 2.064, sehingga dimensi ini termasuk dalam kategori "berketahanan" terhadap ancaman krisis listrik (Gambar 3).

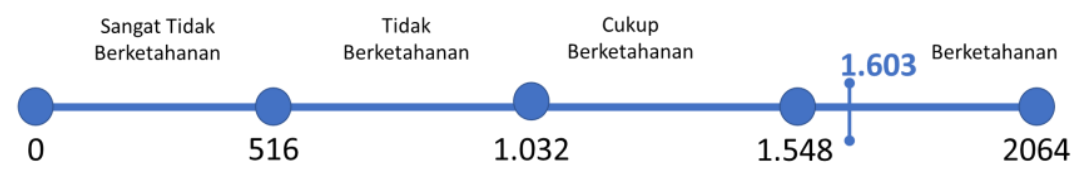

Sumber: Analisis Peneliti, 2017

\section{Gambar 3. Ketahanan Dimensi Ekonomi dan Sosial Masyarakat Kecamatan Jati Agung}

Lebih detail, dimensi ekonomi dan sosial masyarakat memiliki tiga faktor penggerak dan ketiganya memiliki karakteristik ketahanan yang tidakjauh berbeda yang dapat dilihat pada Gambar 4.

a. Aktivitas responden dalam kehidupan bermasyarakat

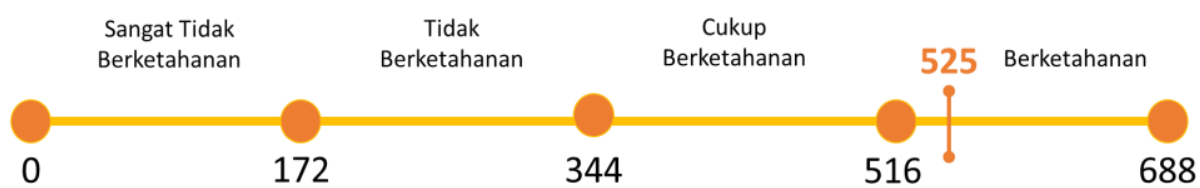

b. Kestabilan sosial/ keamanan di lingkungan masyarakat

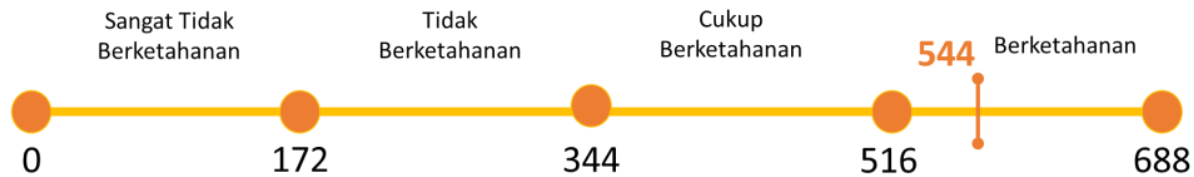

c. Kestabilan aktivitas ekonomi di lingkungan responden

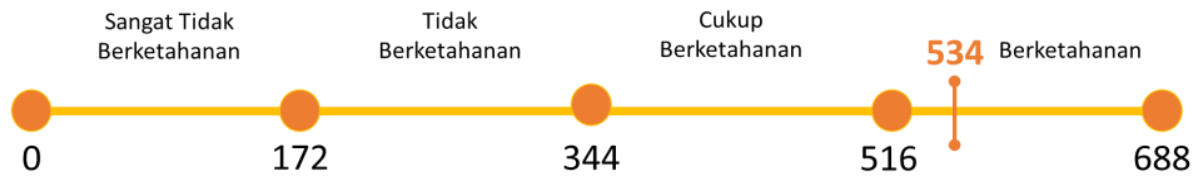

Sumber: Analisis Peneliti, 2017

\section{Gambar 4. Ketahanan Faktor Penggerak Dimensi Ekonomi dan Sosial Masyarakat Kecamatan Jati Agung terhadap Ancaman Krisis Listrik}

Berdasarkan hasil penilaian responden, ketahanan dimensi ekonomi dan sosial masyarakat Kecamatan Jati Agung dinilai berketahanan terhadap ancaman krisis listrik. 
Adapun ketiga faktor penggerak dimensi ekonomi dan sosial masyarakat seluruhnya dinilai berketahanan. Oleh karena itu, dapat disimpulkan bahwa masyarakat Kecamatan Jati Agung dalam kehidupan bermasyarakat, kondisi sosial/keamanan lingkungan dan aktivitas ekonomi di lingkungan sekitar tidak terganggu dengan adanya ancaman krisis listrik di wilayahnya.

\section{Lingkungan dan Infrastruktur}

Secara umum, ketahanan dimensi lingkungan dan infrastruktur masyarakat di Kecamatan Jati Agung terhadap ancaman krisis listrik mendapat skor 1.289 dari 2.064 sehingga dimensi ini termasuk dalam kategori "cukup berketahanan" terhadap ancaman krisis listrik (Gambar 5).

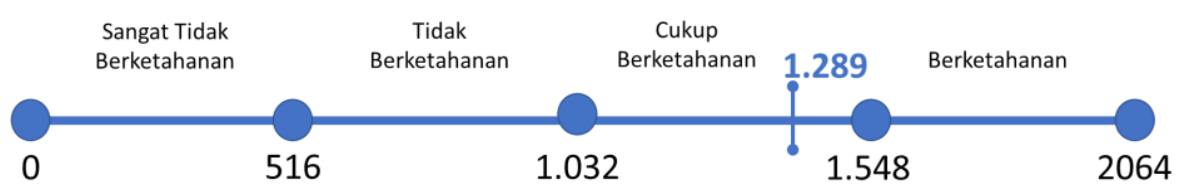

Sumber: Analisis Peneliti, 2017

\section{Gambar 5. Ketahanan Dimensi Lingkungan dan Infrastruktur Kecamatan Jati Agung}

Lebih detail, dimensi lingkungan dan infrastruktur memiliki 3 (tiga) faktor peng gerak dan ketiganya memiliki karakteristik ketahanan yang berbeda yang dapat dilihat pada Gambar 6.

a. Aktivitas pelayanan infrastruktur dasar (air bersih)

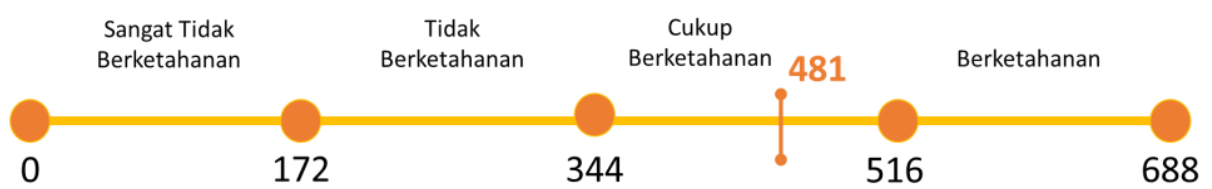

b. Aktivitas pelayanan infrastruktur komunikasi

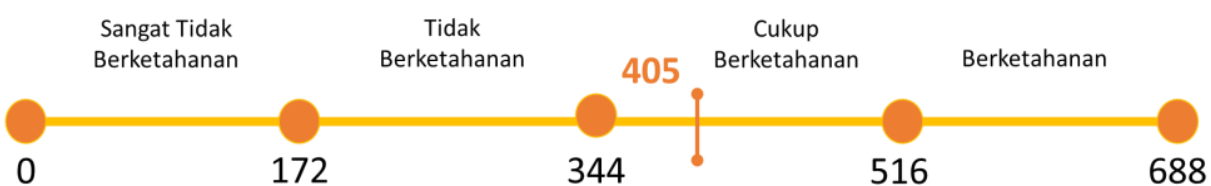

c. Aktivitas pelayanan infrastruktur transportasi (penerangan jalan)

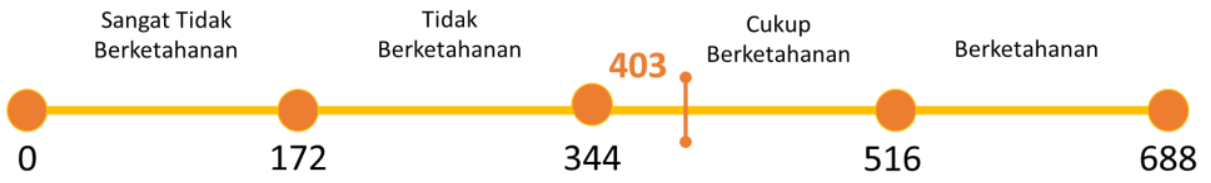

Sumber:Analisis Peneliti, 2017

\section{Gambar 6. Ketahanan Faktor Penggerak Dimensi Lingkungan dan Infrastruktur di Kecamatan Jati Agung terhadap Ancaman Krisis Listrik}

Berdasarkan hasil penilaian responden, ketahanan dimensi lingkungan dan infrastruktur di Kecamatan Jati Agung dinilai cukup berketahanan terhadap ancaman krisis listrik oleh masyarakat. Adapun ketiga faktor penggerak dimensi ini memiliki karakteristik 


\section{Ketahanan Masyarakat terhadap Ancaman Krisis Energi Listrik di Kabupaten Lampung Selatan...}

ketahanan yang tidak berbeda jauh dan ketiganya berada dalam kategori "cukup berketahanan". Jika dikaitkan dengan kondisi eksisting infrastruktur di Kecamatan Jati Agung, sebagian responden tidak menggunakan layanan telepon kabel (atau hampir semuanya menggunakan telepon seluler) sehingga ancaman krisis energi tidak begitu mempengaruhi penggunaan telepon seluler yang mayoritas digunakan warganya. Kondisi yang sama terjadi pada kondisi infrastruktur air bersih. Di Jati Agung, air bersih tidak begitu terpengaruh oleh ancaman listrik. Meskipun demikian, untuk mewujudkan kawasan permukiman yang berketahanan (resilient settlement) sesuai dengan SDGs perlu dilakukan upaya peningkatan ketahanan infrastruktur dan lingkungan terhadap ancaman krisis listrik di Kecamatan Jati Agung.

\section{Kepemimpinan dan Strategi}

Secara umum, ketahanan dimensi kepemimpinan dan strategi masyarakat di Kecamatan Jati Agung terhadap ancaman krisis listrik mendapat skor terendah dari ketiga dimensi lainnya yaitu hanya mencapai 466 dari 2.064 sehingga dimensi ini masuk dalam kategori "sangat tidak berketahanan" terhadap ancaman krisis listrik (Gambar 7).

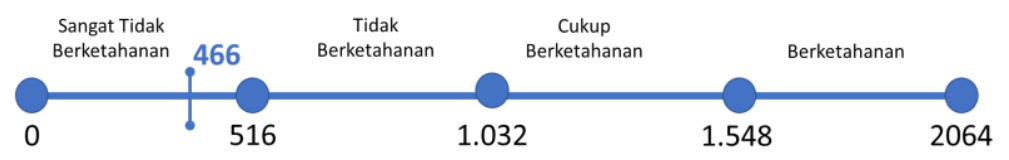

Sumber: Analisis Peneliti, 2017

\section{Gambar 7. Ketahanan Dimensi Kepemimpinan dan Strategi Kecamatan Jati Agung}

Seperti halnya dimensi lainnya, dimensi kepemimpinan dan strategi memiliki tiga faktor penggerak dan ketahanan masing-masing faktor penggerak mempengaruhi langsung dimensi kepemimpinan dan strategi secara langsung. Karakteristik ketahanan dimensi kepemimpinan dan strategi dapat dilihat pada Gambar 8.

a. Sikap tanggap pemimpin lingkungan tempat tinggal

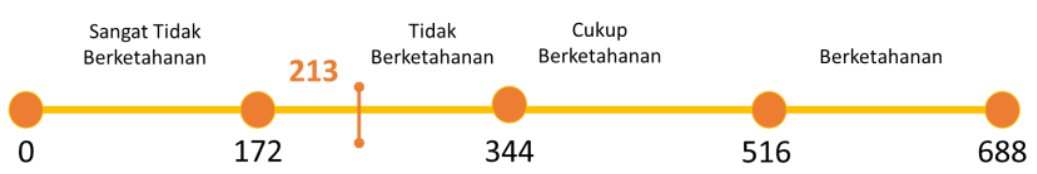

b. Program yang diterapkan oleh pemimpin lingkungan

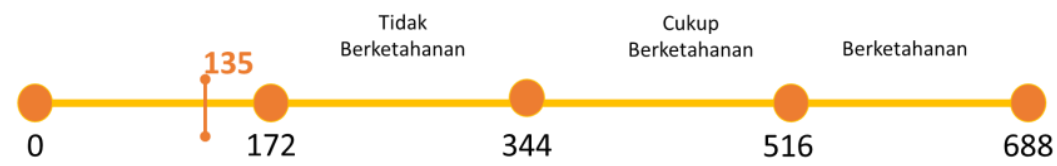

c. Keberlanjutan program penanganan pemadaman listrik

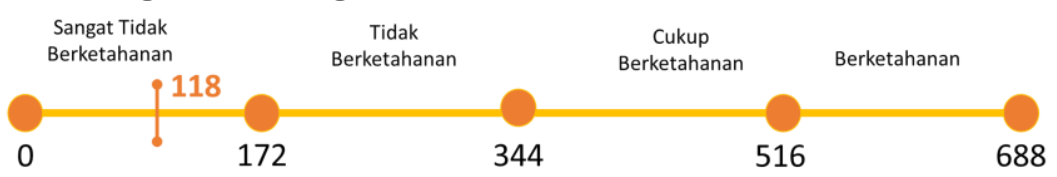

Sumber: Analisis Peneliti, 2017

Gambar 8. Ketahanan Faktor Penggerak Dimensi Kepemimpinan dan Strategi 
Jika dibandingkan dengan dimensi lainnya, dimensi kepemimpinan dan strategi di Kecamatan Agung terhadap ancaman listrik memiliki skor terendah. Hal ini dipengaruhi oleh capaian skor yang rendah pada pada masing-masing faktor penggerak dimensi ini. Jika melihat dari hasil penilaian, terlihat bahwa masyarakat menilai belum ada program baik dari pemerintah maupun masyarakat yang dapat menghadapi ancaman krisis energi listrik. Hal ini dapat dilihat pada program dan keberlanjutan program penanganan pemadaman listrik memiliki skor kecil. Selain itu, sikap tanggap pemimpin lingkungan terkait ancam an krisis energi sangat kurang. Berdasarkan hasil penilaian ketahanan dimensi kepemimpinan dan strategi di Kecamatan Jati Agung, maka dapat disimpulkan bahwa saat ini belum ada local champion yang mampu menjadi pionir untuk tanggap terhadap ancaman krisis listrik di Kecamatan Jati Agung, padahal jika melihat arahan pembangunan, Kecamatan Jati Agung sebagai kota satelit memerlukan dukungan dan kemandirian masyarakat dalam mengelola permasalahan pembangunan yang dihadapi salah satunya adalah ancaman krisis energi listrik di masa yang akan datang.

\section{Kesimpulan}

Ketahanan masyarakat di Kecamatan Jati Agung terhadap ancaman listrik dianggap masih kurang berketahanan. Hal tersebut terjadi karena dari keempat dimensi ketahanan masyarakat Jati Agung terhadap ancaman krisis energi listrik yang dikaji, hanya dimensi ekonomi dan sosial masyarakat yang berketahanan. Sementara itu dimensi kesehatan dan kesejahteraan dan dimensi infrastruktur dan lingkungan cukup berketahanan, sedangkan dimensi kepemimpinan dan strategi tidak berketahanan.

Pemetaan dimensi ketahanan masyarakat di Kecamatan Jati Agung menunjukkan bahwa perlu adanya pembangunan aspek kepemimpinan dan strategi untuk mempersiapkan masyarakat yang berketahanan terhadap ancaman krisis energi. Selain itu, perlu penguatan pada aspek kesehatan dan kesejahteraan serta aspek infrastruktur dan lingkungan supaya ketahanan masyarakat terhadap ancaman krisis meningkat.

Dari segi akademik, penelitian ini menghasilkan pemetaan ketahanan masyarakat berdasarkan dimensi dan faktor penggeraknya. Hasil dari penelitian ini diharapkan dapat menjadi entry point untuk penyusunan strategi ketahanan masyarakat Kecamatan Jati Agung terhadap ancaman krisis energi di masa yang akan datang.

\section{Daftar Pustaka}

Adger, W. N. (2000). Social and ecological resilience: are they related? Progress in Human Geography, 24(3), 347-364.. doi:10.1191/030913200701540465.

Alexander, D. E. (2013). Resilience and disaster risk reduction: An etymological journey. Natural Hazards and Earth System Sciences, 13(11), 2707-2716. doi:10.5194/nhess-13-2707-2013.

Arup \& The Rockefeller Foundation. (2014). City resilience framework. Arup. London, UK and New York, USA. Retrieved from http://www.seachangecop.org/files/documents/URF_Booklet_Final_for_Bellagio.pdf\%5Cnhttp:/ / ww w.rockefellerfoundation.org/uploads/files/0bb537c0--̄872-467f-9470b20f57c32488.pdf\%5Cnhttp://resilient-cities.iclei.org/fileadmin/sites/resilient-cities/files/Image.

Badan Pengkajian dan Penerapan Teknologi (BPPT). (2014). Outlook energi Indonesia 2014: Pengembangan energi untuk mendukung program substitusi BBM. (A. Sugiyono, Anindhita, M. S. Boedoyo, \& Adiarso, Eds.). Jakarta: Pusat Teknologi Pengembangan Sumberdaya Energi, Badan Pengkajian dan Pen erapan Teknologi.

Badan Pusat Statistik (BPS) Kabupaten Lampung Selatan. (2016). Jati Agung dalam angka 2016. Lampung Selatan: Badan Pusat Statistik Kabupaten Lampung Selatan.

Buikstra, E., Ross, H., King, C. A., Baker, P. G., Hegney, D., McLachlan, K., \& Rogers-Clark, C. (2010). The components of resilience-perceptions of an Australian rural community. Journal of Community 


\section{Ketahanan Masyarakat terhadap Ancaman Krisis Energi Listrik di Kabupaten Lampung Selatan...}

Psychology, 38(5), 607-621. doi:10.1002/jcop.20409.

Carpenter, S., Walker, B., Anderies, J. M., \& Abel, N. (2001). From metaphor to measurement: Resilience of what to what? Ecosystems, 4(8), 765-781. doi:10.1007/s10021-001-0045-9.

Community and Regional Resilience Institute (CARRI). (2013). Definitions of community resilience: An analysis. community and regional resilience institute (CARRI). Retrieved from http://www.resilientus.org/library/CARRI_Definitions_Dec_2009_1262802355.pdf.

Folke, C. (2006). Resilience: The emergence of a perspective for social-ecological systems analyses. Global Environmental Change, 16(3), 253-267. doi:10.1016/j.gloenvcha.2006.04.002.

Goulden, M. C., Adger, W. N., Allison, E. H., \& Conway, D. (2013). Limits to resilience from livelihood diversification and social capital in lake social-ecological systems. Annals of the Association of American Geographers, 103(4), 906-924. doi:10.1080/00045608.2013.765771.

Hermawan, B. (2016). PLN: Pemadaman bergilir di Lampung berlanjut hingga Juli 2017. Retrieved from http://www.republika.co.id/berita/nasional/daerah/16/03/17/o45rfp354-pln-pemadaman-bergilir-dilampung-berlanjut-hingga-juli-2017.

Holling, C. S. (1973). Resilience and Ecological Systems. Annual Review of Ecology and Systematics, 4, 1-23. doi:10.1146/annurev.es.04.110173.000245.

Kementerian Energi dan Sumber Daya Mineral (ESDM). (2015). Panduan pengguna untuk sektor rumah tangga. Jakarta: Kementerian Energi dan Sumber Daya Mineral. Retrieved from http://papua2050.wwf.id/assets/mini_paper/energy/id/Panduan Pengguna untuk Sektor Rumah Tangga.pdf.

Marschke, M. J., \& Berkes, F. (2006). Exploring strategies that build livelihood resilience: A case from Cambodia. Ecology and Society, 11(1), 42-57. Retrieved from https://www.ecologyandsociety.org/vol11/iss1/art42/ES-2006-1730.pdf,

Nyamwanza, A. M. (2012). Livelihood resilience and adaptive capacity: A critical conceptual review. Jàmbá: Journal of Disaster Risk Studies, 4(1), 1-6. doi:10.4102/jamba.v4i1.55.

O’Brien, G., \& Hope, A. (2010). Localism and energy: Negotiating approaches to embedding resilience in energy systems. Energy Policy, 38(12), 7550-7558. doi:10.1016/j.enpol.2010.03.033.

Rockefeller Foundation and ISET. (2010). Training modul for city resilience strategy technical workshop. Bangkok.

Sugiyono. (2008). Memahami penelitian kualitatif. Bandung: Alfabeta.

Speranza, C. I., Wiesmann, U., \& Rist, S. (2014). An indicator framework for assessing livelihood resilience in the context of social-ecological dynamics. Global Environmental Change, 28(1), 109-119. doi:10.1016/j.gloenvcha.2014.06.005.

Tanner, T., Lewis, D., Wrathall, D., Bronen, R., Cradock-Henry, N., Huq, S., ... Thomalla, F. (2015). Livelih o o d resilience in the face of climate change. Nature Climate Change, 5(1), 23-26. doi:10.1038/nclimate2431. 